\title{
Tumor necrosis factor- $\alpha$ and $-\beta$ genetic polymorphisms as a risk factor in Saudi patients with schizophrenia
}

This article was published in the following Dove Press journal:

Neuropsychiatric Disease and Treatment

I2 April 2017

Number of times this article has been viewed

\author{
Saeed Kadasah' \\ Misbahul Arfin ${ }^{2}$ \\ Sadaf Rizvi \\ Mohammed Al-Asmari ${ }^{2}$ \\ Abdulrahman Al-Asmari² \\ 'Department of Psychiatry, ${ }^{2}$ Division \\ of Molecular Biology \& Genetics, \\ Scientific Research Center, \\ Prince Sultan Military Medical City, \\ Riyadh, Saudi Arabia
}

Background: Schizophrenia is one of the most common devastating psychiatric disorders that negatively affects the quality of life and psychosocial functions. Its etiology involves the interplay of complex polygenic influences and environmental risk factors. Inflammatory markers are well-known etiological factors for psychiatric disorders, including schizophrenia.

Objective: The aim of this study was to investigate the association of proinflammatory cytokine genes, tumor necrosis factor (TNF)- $\alpha(-308 \mathrm{G} / \mathrm{A})$ and TNF- $\beta(+252 \mathrm{~A} / \mathrm{G})$ polymorphisms with schizophrenia susceptibility.

Subjects and methods: $T N F-\alpha$ and $T N F-\beta$ genes were amplified using amplification refractory mutation system primers in 180 schizophrenia patients and 200 healthy matched controls recruited from the Psychiatry Clinic of Prince Sultan Military Medical City, Riyadh. The frequencies of alleles and genotypes of TNF- $\alpha(-308 \mathrm{G} / \mathrm{A})$ and TNF- $\beta(+252 \mathrm{~A} / \mathrm{G})$ polymorphisms in patients were compared with those in controls.

Results: The frequencies of TNF- $\alpha(-308)$ allele A and genotype GA were significantly higher, while those of allele $\mathrm{G}$ and genotype GG were lower in schizophrenia patients as compared to controls, indicating that genotype GA and allele A of TNF- $\alpha(-308 \mathrm{G} / \mathrm{A})$ may increase susceptibility to schizophrenia, while genotype GG and allele G may reduce it. On the other hand, the distribution of alleles and genotypes of TNF- $\beta(+252 \mathrm{~A} / \mathrm{G})$ polymorphism does not differ significantly in patients from controls; however, the frequency of genotype GG of TNF- $\beta$ $(+252 \mathrm{~A} / \mathrm{G})$ was significantly higher in male patients than in female patients. The distribution of TNF- $\alpha(-308 \mathrm{G} / \mathrm{A})$ and TNF- $\beta(+252 \mathrm{~A} / \mathrm{G})$ polymorphisms was almost similar in schizophrenia patients with negative or positive symptoms.

Conclusion: TNF- $\alpha(-308 \mathrm{G} / \mathrm{A})$ and TNF- $\beta$ (+252G/A) polymorphisms may increase the susceptibility to schizophrenia in Saudi patients and could be a potential risk factor for its etiopathogenesis. However, further studies are warranted involving a larger sample size to strengthen our findings.

Keywords: schizophrenia, tumor necrosis factor, gene polymorphism, genetics, psychiatric disorder

\section{Introduction}

Schizophrenia is one of the most common devastating psychiatric disorders with a lifetime morbidity risk of $0.5 \%-2.7 \%$ and heritability estimated at up to $80 \%{ }^{1-3}$ The genetic, neurodevelopmental, neurotransmitter, and neuroimmunological hypotheses have been suggested to explain the etiopathogenesis of schizophrenia. ${ }^{4,5}$ It involves the interplay of complex polygenic influences and environmental risk factors operating on brain maturational processes.
Correspondence: Abdulrahman Al-Asmari Scientific Research Centre, Prince Sultan Military Medical City, PO Box 7897, Riyadh II I59, Saudi Arabia Email abdulrahman.alasmari@gmail.com 
Multiple genes have been associated with the development of schizophrenia. Recent studies have confirmed the association of a large number of single-nucleotide polymorphisms in a variety of genes with schizophrenia susceptibility. ${ }^{6-11}$ Genes encoding cytokines seem to be good candidate genes for schizophrenia. Cytokines play an important role in the central nervous system (CNS) as essential mediators of crosstalk between the brain and immune system and regulate neuroinflammatory processes. ${ }^{12}$ Some cytokines are normally produced in the healthy brain, where they play critical roles in neurogenesis, migration, differentiation, and synapse formation. ${ }^{13-15}$ The concentrations of these cytokines have been reported to be increased or decreased in patients with schizophrenia. ${ }^{16}$ Moreover, the concentrations of the cytokines in the blood serum of schizophrenia patients may vary depending on whether the patient is in active or resting phase of the disease. ${ }^{17}$ It has also been suggested that schizophrenia may be associated with alterations in the Th1/Th2 cytokine ratios, with a shift toward the Th2 system. ${ }^{4,18,19}$

Cytokines are the key regulators of immune/inflammatory reactions and influence the dopaminergic, noradrenergic, and serotonergic neurotransmission. ${ }^{20}$ Tumor necrosis factor (TNF)- $\alpha$, a proinflammatory cytokine, mediates immune and inflammatory responses and plays a key role in the CNS. It is not only actively transported into the CNS but also released from activated glia cells.

TNF- $\alpha$ (MIM 191160) and TNF- $\beta$ or lymphotoxin-alpha (LT- $\alpha$; MIM 153440) are closely related cytokines that share $30 \%$ amino acid residues and use the same cell surface. ${ }^{21}$ Nedwin et $\mathrm{a}^{22}$ reported that the TNF- $\alpha$ and TNF- $\beta$ genes are located in tandem on chromosome 6 between the Class I and Class II cluster of the major histocompatibility complex chromosome (6p21.1-6p21.3) and show close linkage to the genes for human leukocyte antigen (HLA) classes I (HLA-B) and II (HLA-DR). The production of TNF- $\alpha$ is genetically determined ${ }^{23}$ Several polymorphisms in the promoter region of TNF- $\alpha$ and the intron 1 of TNF- $\beta$ have been associated with changes in the levels of circulating TNF- $\alpha .{ }^{24}$ TNF- $\alpha$ (-308G/A) promoter polymorphism (rs1800629) is one of the best described single-nucleotide polymorphisms at the nucleotide position -308 , which affects a consensus sequence for a binding site of the transcription factor activator protein $2 .{ }^{25} \mathrm{TNF}-\alpha(-308 \mathrm{G} / \mathrm{A})$ polymorphism leads to a less common allele A (2-allele), which has been associated with increased TNF- $\alpha$ production in vitro ${ }^{26}$ and a higher rate of TNF- $\alpha$ transcription than that associated with the wild-type GG genotype ${ }^{27}$ Conversely, a polymorphism TNF- $\beta(+252 \mathrm{~A} / \mathrm{G})$ (rs909253) at the nucleotide position +252 within the first intron of TNF- $\beta$ gene affects a phorbol ester-responsive element. The presence of $\mathrm{G}$ at this position defines the mutant allele known as TNF- $\beta * 1$ (1-allele), which is associated with higher TNF- $\alpha$ and $-\beta$ production. ${ }^{28,29}$ The functional polymorphisms in cytokine genes may result in imbalances in the pro- and anti-inflammatory cytokine production. ${ }^{11}$ Keeping in view the potential role of these cytokines as the principal mediators of the immune response and the importance of the chromosomal region containing TNF- $\alpha$ and TNF- $\beta$ genes, the present study was undertaken to examine the association of TNF- $\alpha(-308 \mathrm{G} / \mathrm{A})$ and TNF- $\beta(+252 \mathrm{G} / \mathrm{A})$ polymorphisms with schizophrenia susceptibility in Saudi population. The concomitant analysis of polymorphisms at $T N F-\alpha$ and $-\beta$, given that both are involved in the expression of TNF- $\alpha$, will help in the development of better strategies for the prevention and treatment of schizophrenia.

\section{Subjects and methods Subjects}

The study population consisted of a total of 380 Saudi subjects of either sex. The sample included 180 schizophrenia patients recruited from the Outpatient Psychiatric Clinic of Prince Sultan Military Medical City, Riyadh, Saudi Arabia, and 200 age- and sex-matched healthy subjects as controls. All subjects were biologically unrelated Saudis. To ensure the diagnostic reliability, a systemic search into the case notes of the patients was made. Out of 200 initially selected schizophrenia patients, 20 patients failed to meet the explicit stated criteria and hence were excluded, and only 180 patients were included in this study. Among the confirmed 180 cases of schizophrenia, there were 53 females and 127 males with a mean age of $39 \pm 12.5$ years and a mean disease duration of $9 \pm 4.5$ years. Age at the onset of disease ranged from 19 to 64 years (mean 29 \pm 2.5 years). Among the confirmed cases of schizophrenia, 94 patients had negative symptoms, while 86 patients had positive symptoms. The female to male ratio of schizophrenia patients in our study was 53:127 (1:2.4). The control group consisted of 60 females and 140 males aged $26-60$ years with a mean age of $35 \pm 10.5$ years. Power was calculated online (http://www.stat.ubc.ca/ rollin/stats/ $\underline{\text { ssize/caco.html). }}$.

The diagnosis of schizophrenia was based on the criteria mentioned in the American Psychiatric Association's Diagnostic and Statistical Manual of Mental Disorders, Fourth Edition, Text Revision version. The patients were further assessed for positive and negative symptoms using Positive and Negative Syndrome Scale as described by Kay et al. ${ }^{30}$ 
All subjects in the control group were screened and excluded if they had any history of neurological, psychiatric, or medical disorders or had a past or present involvement in substance abuse. Screening of controls was performed following Johnstone et al. ${ }^{31}$ None of the control subjects had a first- or second-degree relative with any mental illness. This study was approved by the research and ethical committee of Prince Sultan Military Medical City (PSMMC). Written informed consent was obtained from all subjects in accordance with ethical guidelines set by the ethical committee.

\section{Polymerase chain reaction (PCR) amplification}

Genomic DNA was extracted from the peripheral blood of Schizophrenia patients and controls using QIAamp ${ }^{\mathrm{R}}$ DNA Mini Kit (Qiagen, Valencia, CA, USA). TNF- $\alpha$ and TNF- $\beta$ genes were amplified using an amplification refractory mutation system-PCR methodology to detect any polymorphism involved at positions -308 of TNF- $\alpha$ and +252 in intron 1 of TNF- $\beta$ gene. PCR amplification was carried out using PuReTaq Ready-to-Go PCR Beads (GE Healthcare, Buckinghamshire, UK) as described elsewhere. ${ }^{32}$ The molecular analysis of the samples was performed in the same laboratory and at the same time. The investigator was blind to the phenotype of the subjects at the time of molecular analysis. Later on, the results were separated for patient and control groups and analyzed for the determination of the frequencies of genotypes and alleles.

\section{Statistical analysis}

The differences in allele/genotype frequencies between patients and controls were analyzed by the Fisher's exact test. $P$-values $\leq 0.05$ were considered significant. Bonferroni correction was applied to minimize error due to multiple comparison test. Therefore, both the $P$-values, after Bonferroni correction and Fisher's exact test, are considered in the manuscript and Tables 1-3.
The odd ratio interpreted as relative risk (RR) was calculated following the Woolf's method as outlined by Schallreuter et al. ${ }^{33}$ The etiologic fraction (EF) and preventive fraction (PF) were calculated following the formula of Svejgaard et $\mathrm{al}^{34}$ as described in our earlier publication. ${ }^{35}$

\section{Results}

Among Schizophrenia patients, the male to female ratio was 127:53 (2.4:1). The number of controls per case was 1.11, which yielded a power of $95 \%$. In this case-control study, the allele and genotype frequencies of both polymorphisms were determined in schizophrenia patients and unrelated matched controls. The results of the genotype and allele distributions of TNF- $\alpha(-308)$ and TNF- $\beta(+252 \mathrm{~A} / \mathrm{G})$ polymorphisms in schizophrenia and control groups are summarized in Tables 1-4. The representative gel pictures for different genotypes are shown in Figures 1 and 2. Allelic frequencies and genotype distributions of both $T N F-\alpha$ and $T N F-\beta$ gene polymorphisms differ between schizophrenia patients and control subjects. The frequency of GA (-308) genotype was significantly higher $(P \leq 0.0001, P=0.0005$, Bonferroni corrected), while the frequency of GG $(-308)$ genotype was lower in patients as compared to controls ( $P \leq 0.0001$, $P=0.0005$, Bonferroni corrected). AA genotype was absent in the patients but present in $7 \%$ of the controls. The frequency of allele A was found to be significantly increased, while that of allele $\mathrm{G}$ was decreased in patients as compared to controls $(P \leq 0.0001)$. Even after applying Bonferroni correction, the $P$-values were statistically significant for both genotypes and alleles (Table 1).

The results of TNF- $\alpha(-308 \mathrm{G} / \mathrm{A})$ polymorphism for the patient group were then stratified into patients with negative or positive symptoms. The distribution of alleles and genotypes of TNF- $\alpha(-308 \mathrm{G} / \mathrm{A})$ polymorphism was found to be similar in the two groups of schizophrenia patients (data not shown).

Our study on $T N F-\beta$ gene polymorphism at position +252 of intron 1 showed that although the frequencies of genotypes

Table I Genotype and allele frequencies of TNF- $\alpha(-308 \mathrm{G} / \mathrm{A})$ variants in schizophrenia patients and matched controls

\begin{tabular}{|c|c|c|c|c|c|c|c|}
\hline \multirow[t]{2}{*}{ Genotype/allele } & \multicolumn{2}{|c|}{$\begin{array}{l}\text { Schizophrenia } \\
(n=180)\end{array}$} & \multicolumn{2}{|c|}{$\begin{array}{l}\text { Control } \\
(n=200)\end{array}$} & \multirow[t]{2}{*}{$P$-value ${ }^{a, b}$} & \multirow[t]{2}{*}{$\mathbf{R R}$} & \multirow[t]{2}{*}{ EFc/PF } \\
\hline & $\mathbf{n}$ & $\%$ & $\mathbf{n}$ & $\%$ & & & \\
\hline GG & 4 & 2.22 & 110 & 55 & $<0.0001$ & 0.042 & 0.444 \\
\hline GA & 176 & 97.78 & 76 & 38 & $<0.0001$ & 71.789 & $0.688^{c}$ \\
\hline $\mathrm{AA}$ & 0 & 0.00 & 14 & 7 & 0.0001 & - & - \\
\hline G-allele (TNF- $\alpha$ I-allele) & 184 & 51.11 & 296 & 74 & $<0.0001$ & 0.367 & 0.389 \\
\hline A-allele (TNF- $\alpha$ 2-allele) & 176 & 48.89 & 104 & 26 & $<0.0001$ & 2.722 & $0.397^{c}$ \\
\hline
\end{tabular}

Notes: aStatistically significant using Fisher's exact test. ${ }^{b} P=0.0005$, Bonferroni corrected. 'Data for EF.

Abbreviations: TNF, tumor necrosis factor; n, number of subjects; RR, relative risk; EF, etiologic fraction; PF, preventive fraction. 
Table 2 Genotype and allele frequencies of TNF- $\beta$ (LT- $\alpha)$ intron I +252 variants in Schizophrenia patients with negative or positive symptoms and matched controls

\begin{tabular}{|c|c|c|c|c|c|c|}
\hline \multirow[t]{2}{*}{$\begin{array}{l}\text { Genotypel } \\
\text { allele }\end{array}$} & \multicolumn{2}{|c|}{$\begin{array}{l}\text { With negative } \\
\text { symptoms }(n=94)\end{array}$} & \multicolumn{2}{|c|}{$\begin{array}{l}\text { With positive } \\
\text { symptoms }(n=86)\end{array}$} & \multicolumn{2}{|c|}{$\begin{array}{l}\text { Control } \\
(n=200)\end{array}$} \\
\hline & $\mathbf{n}$ & $\%$ & $\mathbf{n}$ & $\%$ & $\mathbf{n}$ & $\%$ \\
\hline GG & II & 11.70 & II & 12.79 & 28 & 14 \\
\hline GA & 79 & 84.04 & 65 & 75.58 & 148 & 74 \\
\hline $\mathrm{AA}$ & 4 & $4.26^{\mathrm{a}, \mathrm{b}}$ & 10 & 11.63 & 24 & 12 \\
\hline G-allele & 101 & 53.72 & 87 & 50.58 & 204 & 51 \\
\hline A-allele & 87 & 46.28 & 85 & 49.42 & 196 & 49 \\
\hline
\end{tabular}

Notes: ${ }^{a} P=0.034$ as compared to controls (using Fisher's exact test). ${ }^{b} P=0.034$, Bonferroni corrected.

Abbreviations: TNF, tumor necrosis factor; LT- $\alpha$, lymphotoxin-alpha; $n$, number of subjects.

and alleles differed in patients from controls, the difference was not statistically significant (Table 4). Upon stratification of results of schizophrenia into patients with negative symptoms or with positive symptoms, the distribution of genotypes and alleles of TNF- $\beta(+252 \mathrm{~A} / \mathrm{G})$ polymorphism retained almost the same pattern in the two groups of patients as was in the combined schizophrenia patients except that the frequency of genotype AA was significantly lower in patients with negative symptoms than in those with positive symptoms or controls (Table 2, $P=0.034)$. However, the sex difference was clear in the distribution of genotype frequencies of TNF- $\beta(+252 \mathrm{~A} / \mathrm{G})$ polymorphism. The frequency of genotype GG was significantly higher in male patients than in female patients, while the reverse was found for genotype GA, being higher in female patients than in male patients (Table 3 ).

\section{Discussion}

The higher frequencies of genotype GA and allele A of TNF- $\alpha(-308 \mathrm{G} / \mathrm{A})$ in schizophrenia patients as compared to controls indicated that the genotype GA and allele A may be susceptible to schizophrenia $(\mathrm{RR}=71.789, \mathrm{EF}=0.688$ and $\mathrm{RR}=2.722, \mathrm{EF}=0.397$, respectively). The genotype $\mathrm{GG}$ and

Table 3 Genotype and allele frequencies of TNF- $\beta$ (-252A/G) polymorphism in male and female patients

\begin{tabular}{|c|c|c|c|c|c|c|}
\hline \multirow[t]{2}{*}{$\begin{array}{l}\text { Genotype/ } \\
\text { allele }\end{array}$} & \multicolumn{2}{|c|}{$\begin{array}{l}\text { Female } \\
(n=53)\end{array}$} & \multicolumn{2}{|c|}{$\begin{array}{l}\text { Male } \\
(n=127)\end{array}$} & \multirow[t]{2}{*}{$P$-value } & \multirow[t]{2}{*}{ RR } \\
\hline & $\mathbf{n}$ & $\%$ & $\mathbf{n}$ & $\%$ & & \\
\hline$\overline{G G}$ & 2 & 3.77 & 20 & 15.75 & $0.025^{\mathrm{a}, \mathrm{b}}$ & 0.209 \\
\hline GA & 49 & 92.46 & 95 & 74.80 & $0.007^{\mathrm{a}, \mathrm{c}}$ & 4.126 \\
\hline AA & 2 & 3.77 & 12 & 9.45 & 0.238 & 0.376 \\
\hline G-allele & 53 & 50.00 & 135 & 53.15 & 0.643 & 0.881 \\
\hline A-allele & 53 & 50.00 & 119 & 46.85 & 0.643 & 1.134 \\
\hline
\end{tabular}

Notes: ${ }^{2}$ Statistically significant using Fisher's exact test. ${ }^{b} P=0.05$, Bonferroni corrected. $c P=0.01$, Bonferroni corrected.

Abbreviations: TNF, tumor necrosis factor; $n$, number of subjects; RR, relative risk. allele $\mathrm{G}$ being higher in controls than in patients show their protective nature for schizophrenia $(\mathrm{RR}=0.042, \mathrm{PF}=0.444$ and $R R=0.367, P F=0.389$, respectively). These results suggested that TNF- $\alpha(-308 \mathrm{G} / \mathrm{A})$ polymorphism may increase the susceptibility to schizophrenia in the Saudi population and support the possible role of the immune response system in the pathogenesis of schizophrenia as suggested earlier by various researchers. ${ }^{3,4}$

The results of the present study are in accordance with earlier reports indicating the association of allele $\mathrm{A}$ of TNF- $\alpha(-308 \mathrm{G} / \mathrm{A})$ in the etiology of schizophrenia in Italian,,${ }^{36,37}$ Brazilian, ${ }^{38}$ Singaporean, ${ }^{39}$ Pakistani, ${ }^{40}$ and Polish population. ${ }^{3}$ On the other hand, some reports indicated the association of allele G of TNF- $\alpha(-308 \mathrm{G} / \mathrm{A})$ with schizophrenia in German, ${ }^{41}$ Finnish male, ${ }^{42}$ Australian, ${ }^{43}$ and Polish populations. ${ }^{44}$ Contrarily, several reports indicated no association of TNF- $\alpha$ (-308G/A) polymorphism with the susceptibility or pathogenesis of schizophrenia in the German, ${ }^{45}$ Korean, ${ }^{46}$ Australian, Indian Fijian, Indigenous Fijian, and Brahmin populations of India ${ }^{47}$ and in Taiwanese, ${ }^{48}$ Japanese, ${ }^{49,50}$ Chinese Han, ${ }^{51}$ Finnish, ${ }^{42,52}$ American Caucasian, ${ }^{53}$ and Canadian populations. ${ }^{54}$ These variations in the association of TNF- $\alpha(-308 \mathrm{G} / \mathrm{A})$ polymorphism with schizophrenia in various ethnic populations may be due to ethnic differences in the distribution of this polymorphism worldwide. The distribution of TNF- $\alpha(-308 \mathrm{G} / \mathrm{A})$ polymorphism is not uniform in healthy populations, and the frequencies vary from 50 to $98,1.96$ to 40.5 , and 0 to $11.9 \%$ for GG, GA, and AA genotypes, respectively, in different ethnic populations, showing ethnic variations. ${ }^{55}$ However, the association of the TNF- $\alpha$ (-308G/A) promoter polymorphism with schizophrenia in the Saudi population and other ethnicities has complemented the clinical findings of increased levels of TNF- $\alpha$ in schizophrenic patients, with some support for a functional consequence of the variant as allele $\mathrm{A}$ has been associated with increased TNF- $\alpha$ production in vitro ${ }^{26}$ and a higher rate of TNF- $\alpha$ transcription than the wild-type GG genotype. ${ }^{27}$ Alterations in the serum TNF- $\alpha$ level of chronic schizophrenia patients have been reported previously, ${ }^{56-58}$ implicating the role of TNF- $\alpha$ and TNF- $\alpha$-related signaling pathways in the pathophysiology of schizophrenia. The roles of TNF- $\alpha$ in controlling neuronal excitability and metabolisms of glutamate, dopamine, and serotonin neurotransmitters have made it an outstanding candidate for etiology and pathophysiology of schizophrenia. ${ }^{59}$ It has been suggested that TNF- $\alpha$ may be a trait marker of schizophrenia and may have an important role in the psychopathology of schizophrenia. ${ }^{60,61}$ The increased level of TNF- $\alpha$ may increase 
Table 4 Genotype and allele frequencies of TNF- $\beta($ LT $-\alpha)$ intron I +252 variants in schizophrenia patients and matched controls

\begin{tabular}{|c|c|c|c|c|c|c|c|}
\hline \multirow[t]{2}{*}{ Genotype/allele } & \multicolumn{2}{|c|}{$\begin{array}{l}\text { Schizophrenia } \\
(n=\mid 80)\end{array}$} & \multicolumn{2}{|c|}{$\begin{array}{l}\text { Control } \\
(n=200)\end{array}$} & \multirow[t]{2}{*}{$P$-value } & \multirow[t]{2}{*}{$\mathbf{R R}$} & \multirow[t]{2}{*}{$E F^{a} / P F$} \\
\hline & $\mathbf{n}$ & $\%$ & $\mathbf{n}$ & $\%$ & & & \\
\hline GG & 22 & 12.22 & 28 & 14 & 0.650 & 0.855 & 0.744 \\
\hline GA & 144 & 80.00 & 148 & 74 & 0.181 & 1.405 & $0.142^{\mathrm{a}}$ \\
\hline AA & 14 & 7.78 & 24 & 12 & 0.230 & 0.618 & 0.185 \\
\hline G-allele (TNF- $\beta$ I-allele) & 188 & 52.22 & 204 & 51 & 0.771 & 1.050 & $0.023^{\mathrm{a}}$ \\
\hline A-allele (TNF- $\beta$ 2-allele) & 172 & 47.78 & 196 & 49 & 0.771 & 0.952 & 0.229 \\
\hline
\end{tabular}

Note: aData for EF.

Abbreviations: TNF, tumor necrosis factor; LT- $\alpha$, lymphotoxin-alpha; $n$, number of subjects; RR, relative risk; EF, etiologic fraction; PF, preventive fraction.

the production of 3-hydroxykynurenine. The increase in ratio between neurotoxic 3-hydroxykynurenine and neuroinhibitory/neuroprotective kynurenic acid may account for altered neurogenesis and structural abnormalities characteristic of schizophrenia. ${ }^{62}$ However, Morar et al ${ }^{43}$ besides supporting the association with the TNF- $\alpha(-308 \mathrm{G} / \mathrm{A})$ promoter polymorphism emphasized a linkage to the major histocompatibility complex region where the TNF- $\alpha$ gene is located and suggested linkage disequilibrium rather than direct involvement in the disorder. Paul-Samojedny et $\mathrm{al}^{3}$ investigated the combined impact of gene polymorphisms in three proinflammatory cytokines, namely, IL-2, IL-6, and TNF- $\alpha$, on susceptibility to schizophrenia and hypothesized that $I L-6$ and $T N F-\alpha$ gene polymorphisms that contribute to changes in the cytokine levels may impair the immune response to infections and also affect the development of the normal brain. The precise neurobiological mechanism explaining these increased risks in relation to infections is not clear, although the role of cytokines and an impaired immune response to these infections during the critical period of brain development are documented. ${ }^{63}$ Because of the fact that particular schizophrenia subtypes are characterized by different clinical pictures, it is reasonable to perform genetic

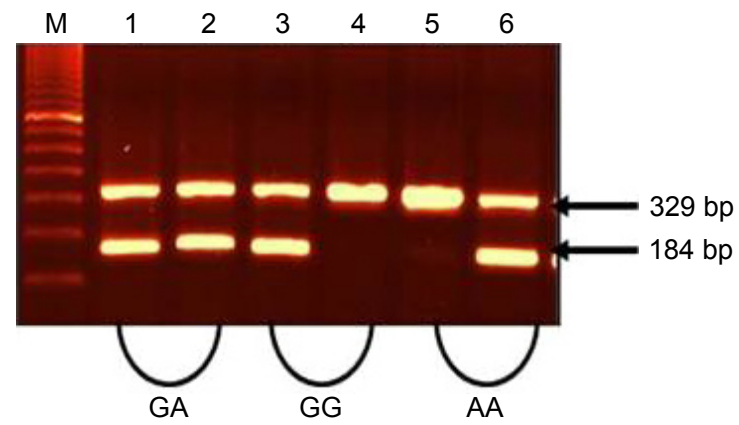

Figure I Amplification of TNF- $\alpha(-308 \mathrm{G} / \mathrm{A})$ alleles ( $\mathrm{G}$ and $\mathrm{A})$.

Notes: Lane M: 100 bp DNA marker; lanes I and 3: amplification of allele G; lanes 2 and 6: amplification of allele A; 184 bp band for target DNA and 329 bp band for internal control.

Abbreviation: TNF, tumor necrosis factor. association studies on homogenous groups of patients. Therefore, we stratified schizophrenia patients into schizophrenia with positive symptoms and schizophrenia with negative symptoms. However, the distribution of alleles and genotypes was similar in the two groups.

On the other hand, our results for another gene $T N F-\beta$ indicated that TNF- $\beta(+252 \mathrm{~A} / \mathrm{G})$ polymorphism is not directly associated with schizophrenia in Saudi patients; however, the fact that this polymorphism might be in linkage disequilibrium with $T N F-\alpha$ or other gene located in the same region cannot be ruled out. The $T N F-\beta$ gene is known to play a central role in neurodevelopment, synaptic plasticity, and the response to neural injury ${ }^{64}$ Repeatedly associated with various brain activities and having immunologic, neurochemical, neuroendocrine, and behavioral effects, the TNF- $\beta$ gene has also been associated with symptoms of schizophrenia. ${ }^{65}$ In contrast to studies of $T N F-\alpha$, few reports are available on the association between $T N F-\beta$ gene polymorphisms and susceptibility to schizophrenia. ${ }^{41,66-68}$ The immunomodulatory functions of TNF- $\beta$ is well known and could impact the pathophysiology of schizophrenia. It affects and modulates production of TNF- $\alpha$, which is supposed to be involved in the development of schizophrenia. In addition, TNF- $\beta$ is

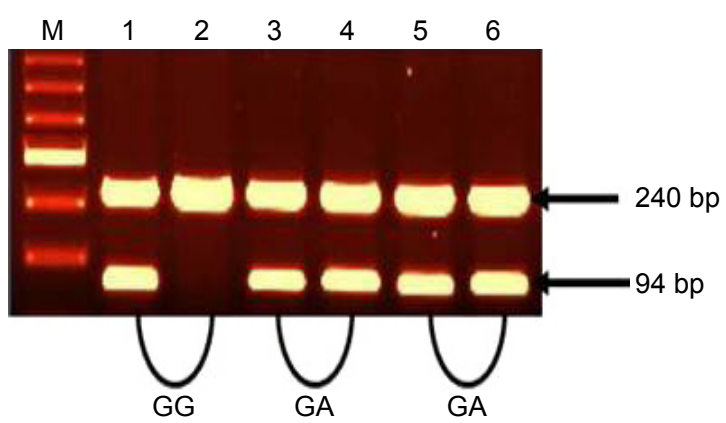

Figure 2 Amplification of TNF- $\beta$ ( $+252 A / G)$ alleles (A and $G)$.

Notes: Lane M: 100 bp DNA marker; lanes I, 3, and 5: amplification of allele G; lanes 4 and 6: amplification of allele A; 94 bp band for target DNA and 240 bp band for internal control.

Abbreviation: TNF, tumor necrosis factor. 
effective in the protection of neuronal cells against glutamate and N-methyl-D-aspartate toxicity, which is considered a neurodevelopmental hypothesis of schizophrenia. Moreover, it is also found to be associated with the regulation of glial cells and stimulation of the synthesis and secretion of nerve growth factors in the CNS. ${ }^{69}$

Our results also showed significantly higher frequency of genotype GG of TNF- $\beta(+252 \mathrm{~A} / \mathrm{G})$ in male patients as compared to female patients (Table 3 ). The higher frequency of genotype GG in male patients, which is known to be associated with increased production of TNF- $\alpha$, might be responsible for the higher prevalence of schizophrenia in male subjects than in female subjects. As far as we know, this is the first study that examines the impact of $T N F-\alpha$ and $T N F-\beta$ gene polymorphisms among Saudi patients with schizophrenia. The main limitation of this study is the small sample size, while the strengths of this study lie in the fact that it is the first report on Saudi patients with Schizophrenia, showing association of polymorphisms in $T N F-\alpha$ and $-\beta$ genes. The errors in genotyping both cases and controls have been avoided carefully by using a standard protocol with positive and negative controls. Statistical analysis was performed to obtain $P$-values, RR, EF and PF, and power.

\section{Conclusion}

We suggest that TNF- $\alpha(-308 \mathrm{G} / \mathrm{A})$ and TNF- $\beta$ (+252G/A) polymorphisms may be associated with schizophrenia susceptibility in Saudi patients and could be potential risk factors for its etiopathogenesis. However, further studies are required to strengthen these findings.

\section{Acknowledgment}

The authors thank the Medical Services Department Administration for providing excellent facilities.

\section{Disclosure}

The authors report no conflicts of interest in this work.

\section{References}

1. Saha S, Chant D, Welham J, McGrath J. A systematic review of the prevalence of schizophrenia. PLoS Med. 2005;2(5):e141.

2. McGrath J, Saha S, Chant D, Welham J. Schizophrenia: a concise overview of incidence, prevalence, and mortality. Epidemiol Rev. 2008; 30:67-76.

3. Paul-Samojedny A, Owczarek M, Kowalczyk R, et al. Association of interleukin 2 (IL-2), interleukin 6 (IL-6), and TNF-alpha (TNF- $\alpha$ ) gene polymorphisms with paranoid schizophrenia in a Polish population. J Neuropsychiatry Clin Neurosci. 2013;25(1):72-82.

4. Leonard BE. Is there an immunologic basis for schizophrenia? Expert Rev Clin Immunol. 2005;1(1):103-112.

5. van Os J, Kapur S. Schizophrenia. Lancet. 2009;374(9690):635-645.
6. Allen NC, Bagade S, McQueen MB, et al. Systematic meta-analyses and field synopsis of genetic association studies in schizophrenia: the SzGene database. Nat Genet. 2008;40(7):827-834.

7. Shi J, Gershon ES, Liu C. Genetic associations with schizophrenia: metaanalyses of 12 candidate genes. Schizophr Res. 2008;104(1-3):96-107.

8. Al-Asmary S, Kadasah S, Arfin M, Tariq M, Al-Asmari A. Genetic association of catechol-O-methyltransferase val(158)met polymorphism in Saudi schizophrenia patients. Genet Mol Res. 2014;13(2):3079-3088.

9. Han S, An Z, Luo X, et al. Association between CMYA5 gene polymorphisms and risk of schizophrenia in Uygur population and a meta-analysis. Early Interv Psychiatry. Epub 2015 Sep 24. doi:10.1111/ eip. 12276.

10. Hudson ZD, Miller BJ. Meta-analysis of cytokine and chemokine genes in schizophrenia. Clin Schizophr Relat Psychoses. Epub 2016 Jul 25. doi: 10. 3371/CSRP.HUMI.070516.

11. Srinivas L, Vellichirammal NN, Alex AM, Nair C, Nair IV, Banerjee M. Pro-inflammatory cytokines and their epistatic interactions in genetic susceptibility to schizophrenia. J Neuroinflammation. 2016; 13(1): 105 .

12. Cañavate ML, García de Galdeano A, Arteaga O, et al. Cross-talk between nervous and immune systems: cytokines modulating morphology and function of both systems under stress conditions. In: Méndez-Vilas A, editor. Microscopy: advances in scientific research and education. Vol. 1. Zurbarán, Spain: Formatex Research Center; 2014:414-421.

13. Szelényi J, Vizi ES. The catecholamine-cytokine balance (interaction between the brain and the immune system). Ann N Y Acad Sci. 2007; 1113:311-324.

14. Deverman BE, Patterson PH. Cytokines and CNS development. Neuron. 2009;64(1):61-78.

15. Garay PA, McAllister AK. Novel roles for immune molecules in neural development: implications for neurodevelopmental disorders. Front Synaptic Neurosci. 2010;2:136.

16. Liu L, Jia F, Yuan G, et al. Tyrosine hydroxylase, interleukin-1 $\beta$ and tumor necrosis factor- $\alpha$ are overexpressed in peripheral blood mononuclear cells from schizophrenia patients as determined by semiquantitative analysis. Psychiatry Res. 2010;176(1):1-7.

17. Maes M, Bocchio Chiavetto L, Bignotti S, et al. Effects of atypical antipsychotics on the inflammatory response system in schizophrenic patients resistant to treatment with typical neuroleptics. Eur Neuropsychopharmacol. 2000;10(2):119-124.

18. Müller N, Riedel M, Ackenheil M, Schwarz MJ. Cellular and humoral immune system in schizophrenia: a conceptual reevaluation. World $J$ Biol Psychiatry. 2000;1(4):173-179.

19. Schwarz MJ, Muller N, Riedel M, Ackenheil M. The Th2-hypothesis of schizophrenia: a strategy to identify a subgroup of schizophrenia caused by immune mechanisms. Med Hypotheses. 2001;56(4):483-486.

20. Müller N, Ackenheil M. Psychoneuroimmunology, the cytokine network in the CNS, and the implications for psychiatric disorders. Progr Neuropsychopharmacol Biol Psychiatry. 1998;22(1):1-31.

21. Beutler B, Cerami A. The biology of cachectin/TNF- a primary mediator of the host response. Annu Rev Immunol. 1989;7:625-655.

22. Nedwin GE, Naylor SL, Sakaguchi AY, et al. Human lymphotoxin and tumor necrosis factor genes: structure, homology and chromosomal localization. Nucleic Acids Res. 1985;13(17):6361-6373.

23. Westendorp RG, Langermans JA, Huizinga TW, et al. Genetic influence on cytokine production and fatal meningococcal disease. Lancet. 1997;349(9046):170-173.

24. Sharma S, Ghosh B, Sharma SK. Association of TNF polymorphisms with sarcoidosis, its prognosis and tumour necrosis factor (TNF)- $\alpha$ levels in Asian Indians. Clin Exp Immunol. 2008;151(2):251-259.

25. Abraham LJ, Kroeger KM. Impact of the $-308 \mathrm{TNF}$ promoter polymorphism on the transcriptional regulation of the TNF gene: relevance to disease. J Leukoc Biol. 1999;66(4):562-566.

26. Braun N, Michel U, Ernst BP, et al. Gene polymorphism at position-308 of the tumor-necrosis-factor- $\alpha$ (TNF- $\alpha$ ) in multiple sclerosis and its influence on the regulation of TNF- $\alpha$ production. Neurosci Lett. 1996; 215(2):75-78. 
27. Wilson AG, Symons JA, McDowell TL, McDevitt HO, Duff GW. Effects of a polymorphism in the human tumor necrosis factor a promoter on transcriptional activation. Proc Natl Acad Sci U S A. 1997;94(7): 3195-3199.

28. Messer G, Spengler U, Jung MC, et al. Polymorphic structure of the tumor necrosis factor (TNF) locus: an NcoI polymorphism in the first intron of the human TNF-beta gene correlates with a variant amino acid in position 26 and a reduced level of TNF-beta production. $J$ Exp Med. 1991;173(1):209-219.

29. Abraham LJ, French MA, Dawkins RL. Polymorphic MHC ancestral haplotypes affect the activity of tumour necrosis factor-alpha. Clin Exp Immunol. 1993;92(1):14-18

30. Kay SR, Fiszbein A, Opler LA. The positive and negative syndrome scale (PANSS) for schizophrenia. Schizophr Bull. 1987;13(2):261-276.

31. Johnstone EC, Ebmeier KP, Miller P, Owens DG, Lawrie SM. Predicting schizophrenia: findings from the Edinburgh high-risk study. $\mathrm{Br} J$ Psychiatry. 2005;186:18-25.

32. Al-Harthi F, Zouman A, Arfin M, Tariq M, Al-Asmari A. Tumor necrosis factor- $\alpha$ and $-\beta$ genetic polymorphisms as a risk factor in Saudi patients with vitiligo. Genet Mol Res. 2013;12(3):2196-2204

33. Schallreuter KU, Levenig C, Kuhnl P, Löliger C, Hohl-Tehari M, Berger J Histocompatability antigens in vitiligo: Hamburg study on 102 patients from Northern Germany. Dermatology. 1993;187(3):186-192.

34. Svejgaard A, Platz P, Ryder LP. HLA and disease 1982 - a survey. Immunol Rev. 1983;70:193-218.

35. Kadasah S, Arfin M, Tariq M. HLA-DRB1 association with schizophrenia in Saudi Arabian patients. Int J Psychiatry Clin Pract. 2010;15(2): $112-117$.

36. Boin F, Zanardini R, Pioli R, Altamura CA, Maes M, Gennarelli M. Association between -G308A tumor necrosis factor alpha gene polymorphism and schizophrenia. Mol Psychiatry. 2001;6(1):79-82.

37. Sacchetti E, Bocchio-Chiavetto L, Valsecchi P, et al. -G308A tumor necrosis factor alpha functional polymorphism and schizophrenia risk: meta-analysis plus association study. Brain Behav Immun. 2007;21(4): 450-457.

38. Meira-Lima IV, Pereira AC, Mota GF, et al. Analysis of a polymorphism in the promoter region of the tumor necrosis factor alpha gene in schizophrenia and bipolar disorder: further support for an association with schizophrenia. Mol Psychiatry. 2003;8(8):718-720.

39. Tan EC, Chong SA, Tan CH, Teo YY, Peng K, Mahendran R. Tumor necrosis factor- $\alpha$ gene promoter polymorphisms in chronic schizophrenia. Biol Psychiatry. 2003;54(11):1205-1211.

40. Naz M, Riaz M, Saleem M. Potential role of Neuregulin 1 and TNFalpha (-308) polymorphism in schizophrenia patients visiting hospitals in Lahore, Pakistan. Mol Biol Rep. 2011;38(7):4709-4714.

41. Schwab SG, Mondabona S, Knappb M, et al. Association of tumor necrosis factor alpha gene-G308A polymorphism with schizophrenia Schizophr Res. 2003;65(1):19-25.

42. Hänninen K, Katilab H, Rontuc R, Mattilac KM, Hurme M, Lehtimäki T. Tumor necrosis factor-alpha -G308A polymorphism in schizophrenia in a Finnish population. Neurosci Lett. 2005;385(1):76-81.

43. Morar B, Schwab SG, Albus M, Maier W, Lerer B, Wildenauer DB Evaluation of association of SNPs in the TNF alpha gene region with schizophrenia. Am J Med Genet B Neuropsychiatr Genet. 2007; 144B(3):318-324.

44. Czerski PM, Rybakowski F, Kapelski P, et al. Association of tumor necrosis factor -308G/A promoter polymorphism with schizophrenia and bipolar affective disorder in a polish population. Neuropsychobiology. 2008;57(1-2):88-94.

45. Riedel M, Krönig H, Schwarz MJ, et al. No association between the G308A polymorphism of the tumor necrosis factor-alpha gene and schizophrenia. Eur Arch Psychiatry Clin Neurosci. 2002;252(5): 232-234.

46. Pae CU, Chae JH, Bahk WM, et al. Tumor necrosis factor- $\alpha$ gene polymorphism at position -308 and schizophrenia in the Korean population. Psychiatry Clin Neurosci. 2003;57(4):399-403.
47. Handoko HY, Nancarrow DJ, Hayward NK, et al. Tumor necrosis factor haplotype analysis amongst schizophrenia probands from four distinct populations in the Asia-Pacific region. Am J Med Genet B Neuropsychiatr Genet. 2003;121B(1):1-6.

48. Tsai SJ, Hong CJ, Yu YW, Lin CH, Liu LL. No association of tumor necrosis factor alpha gene polymorphisms with schizophrenia or response to clozapine. Schizophr Res. 2003;65(1):27-32.

49. Hashimoto R, Yoshida M, Ozaki N, et al. Association analysis of the $-308 \mathrm{G}>$ A promoter polymorphism of the tumor necrosis factor alpha (TNF- $\alpha$ ) gene in Japanese patients with schizophrenia. J Neural Transm. 2004;111(2):217-221.

50. Watanabe Y, Muratake T, Kaneko N, Fukui N, Nara Y, Someya T. No association between the tumor necrosis factor-alpha gene promoter polymorphisms and schizophrenia in a Japanese population. Psychiatry Res. 2007;153(1):1-6.

51. Duan S, Xu Y, Chena W, et al. No association between the promoter variants of tumor necrosis factor alpha (TNF- $\alpha$ ) and schizophrenia in Chinese Han population. Neurosci Lett. 2004;366(2):139-143.

52. Kampman O, Anttila S, Illi A, et al. Interaction of tumor necrosis alpha -G308A and epidermal growth factor gene polymorphisms in early-onset schizophrenia. Eur Arch Psychiatry Clin Neurosci. 2005; 255(4):279-283.

53. Shirts BH, Wood J, Yolken RH, Nimgaonkar VL. Association study of IL10, IL1 $\beta$, and IL1RN and schizophrenia using tag SNPs from a comprehensive database: suggestive association with rs 16944 at IL1 $\beta$. Schizophr Res. 2006;88(1-3):235-244.

54. Zai G, Müller DJ, Volavka J, et al. Family and case-control association study of the tumor necrosis factor-alpha (TNF-alpha) gene with schizophrenia and response to antipsychotic medication. Psychopharmacology (Berl). 2006;188(2):171-182.

55. Al-Rayes H, Al-Swailem R, Albelawi M, Arfin M, Al-Asmari A, Tariq M. TNF- $\alpha$ and TNF- $\beta$ gene polymorphism in Saudi rheumatoid arthritis patients. Clin Med Insights Arthritis Musculoskelet Disord. 2011;4:55-63

56. Beumer W, Drexhage RC, De Wit H, Versnel MA, Drexhage HA, Cohen D. Increased level of serum cytokines, chemokines and adipokines in patients with schizophrenia is associated with disease and metabolic syndrome. Psychoneuroendocrinology. 2012;37(12): 1901-1911.

57. Luo $\mathrm{Y}, \mathrm{He} \mathrm{H}$, Zhang M, et al. Elevated serum levels of TNF- $\alpha$, IL-6 and IL-18 in chronic schizophrenic patients. Schizophr Res. 2014;159(2-3): $556-557$.

58. Lv MH, Tan YL, Yan SX, et al. Decreased serum TNF-alpha levels in chronic schizophrenia patients on long-term antipsychotics: correlation with psychopathology and cognition. Psychopharmacology (Berl). 2015; 232(1):165-172.

59. Tian L, Tan Y, Chen D, et al. Reduced serum TNF alpha level in chronic schizophrenia patients with or without tardive dyskinesia Prog Neuropsychopharmacol Biol Psychiatry. 2014;54:259-264.

60. Kubistova A, Horacek J, Novak T. Increased interleukin-6 and tumor necrosis factor alpha in first episode schizophrenia patients versus healthy controls. Psychiatr Danub. 2012;24(suppl 1):S153-S156.

61. Ajami A, Abedian F, Hamzeh Hosseini S, Akbarian E, Alizadeh-Navaei R, Taghipour M. Serum TNF- $\alpha$, IL-10 and IL-2 in schizophrenic patients before and after treatment with risperidone and clozapine. Iran J Immunol. 2014;11(3):200-209.

62. Johansson A, Owe-Larsson B, Asp L, et al. Activation of kynurenine pathway in ex vivo fibroblasts from patients with bipolar disorder or schizophrenia: cytokine challenge increases production of 3-hydroxykynurenine. J Psychiatr Res. 2013;47(11):1815-1823.

63. Ashdown H, Dumont Y, Ng M, Poole S, Boksa P, Luheshi GN. The role of cytokines in mediating effects of prenatal infection on the fetus: implications for schizophrenia. Mol Psychiatry. 2006;11(1):47-55.

64. Stellwagen D, Malenka RC. Synaptic scaling mediated by glial TNFalpha. Nature. 2006;440(7087):1054-1059.

65. Kronfol Z, Remick DG. Cytokines and the brain: implications for clinical psychiatry. Am J Psychiatry. 2000;157(5):683-694. 
66. Jun TY, Pae CU, Chae JH, et al. TNFB polymorphism may be associated with schizophrenia in the Korean population. Schizophr Res. 2003; 61(1):39-45.

67. Dickerson F, Stallings C, Origoni A, Boronow J, Yolken R. C-reactive protein is associated with the severity of cognitive impairment but not of psychiatric symptoms in individuals with schizophrenia. Schizophr Res. 2007;93(1-3):261-265.
68. Arab AH, Elhawary NA. Association between ANKK1 (rs1800497) and LTA (rs909253) Genetic Variants and Risk of Schizophrenia. Biomed Res Int. 2015;2015:821-827.

69. Pae CU. Potential role of lymphotoxin-alpha (tumor necrosis factorbeta) in the development of schizophrenia. Med Hypotheses. 2007; 68(6):1359-1362.

\section{Publish your work in this journal}

Neuropsychiatric Disease and Treatment is an international, peerreviewed journal of clinical therapeutics and pharmacology focusing on concise rapid reporting of clinical or pre-clinical studies on a range of neuropsychiatric and neurological disorders. This journal is indexed on PubMed Central, the 'PsycINFO' database and CAS, and is the official journal of The International Neuropsychiatric Association (INA). The manuscript management system is completely online and includes a very quick and fair peer-review system, which is all easy to use. Visit http://www.dovepress.com/testimonials.php to read real quotes from published authors.

Submit your manuscript here: http://www.dovepress.com/neuropsychiatric-disease-and-treatment-journal 